V.T. Bolonnyi ${ }^{1}$, Cand. Sc. (Tech.), Assoc. Prof., orcid.org/0000-0003-3012-1121, V. Ya. Grudz ${ }^{2}$, Dr. Sc. (Tech.), Prof., orcid.org/0000-0003-1182-2512,

Ya. V. Grudz ${ }^{2}$, Dr. Sc. (Tech.), Prof., orcid.org/0000-0003-3287-3036, V.B.Zapukhliak ${ }^{2}$, Cand. Sc. (Tech.), Assoc. Prof., orcid.org/0000-0002-2502-3896,

T. Ya. Dodyk ${ }^{3}$, orcid.org/0000-0002-8035-7821

\title{
PREDICTION OF TRANSIENT PROCESSES IN OIL PIPELINES WITH THE PURPOSE OF EMERGENCY INCIDENT PREVENTION
}

Purpose. Preventing accidents during the operation of complex oil transportation systems under incomplete loading is considered on the basis of the prediction of the nature of transient pressure pulsations caused by a leap-like change in productivity.

Methodology. The main factors affecting the trouble-free operation of the main oil pipelines are analyzed. The classification of pipe wall defects of the main oil pipelines is given. For each of these types of defects the probable indicators of their occurrence are given based on the experience of operation of domestic main oil pipelines.

Findings. In order to carry out analytical studies and to establish the laws of fluctuation of pressure in the main oil pipeline with road withdrawal, a mathematical model based on the equations of motion and mass conservation of the fluid is built, the withdrawal process is described using the Dirac source function. The implementation of the model was carried out using the principles of operational calculus, which allowed us to obtain an analytical form of the nature description of the time-varying pressure oscillations in the characteristic points of the trace, which makes it possible to establish the amplitude-frequency characteristics of the transient process.

Originality. For the first time, it is proposed to use a piecewise linear approximation of the boundary conditions at the point of origin of leakage for their implementation in the analytical solution of the transient process model in a hypothetical main oil pipeline.

Practical value. According to the obtained method, the distribution of relative values of pressure and mass flowrate at characteristic points of the modelled oil pipeline system is constructed. The influence of time-varying errors in determining the pressure in the point of road withdrawal upon the accuracy of the calculations is evaluated. The results obtained are recommended for use in oil pipelines and complex petroleum-based systems operating under incomplete loading (to prevent emergencies)

Keywords: complex oil transportation system, road withdrawal, change in flowrate, pressure fluctuation

Introduction. Main oil pipelines are industrial technical long-term operation systems. Therefore, there is a need to ensure the reliability of their operation. The oil transportation system of Ukraine is characterized by the fact that the amortization period of its operation is exhausted for $60 \%$ of the total length of all threads. Moreover, about $40 \%$ of domestic oil pipelines have been in service for more than 30 years [1,2]. So reliability increase of domestic oil pipelines operation is a relevant scientific and applied objective.

Operation experience of main oil pipelines has shown that in spite of significant development in design, construction and operation of main oil pipeline structures it is impossible to definitively solve the problem of accidental losses of oil during its transportation occurring when the line as well as technological equipment is depressurized. That happens under individual or simultaneous influence of several of the following factors [3, 4]:

- no or incomplete adherence to specifications at metal rolling enterprises in the process of pipe manufacturing;

- mistakes made at the stages of oil pipeline design and construction;

- omitting to follow the rules of technical operation of technological equipment;

- natural phenomena (seismic, ground motions, vibrations, landslides lead to pipeline destruction).

Based on the deviation from requirements of the technique and state standards in the process of pipe manufacturing for main pipelines possible defects such as bundling, cracks, shock viscosity decreasing and worsening of material elastic properties, etc. are taking place. There may happen pipe bend-

(C) Bolonnyi V.T., Grudz V.Ya., Grudz Ya.V., Zapukhliak V. B., Dodyk T. Ya., 2020 ing in the process of calibration and pipe alteration, that exceed limit standards, as a result metal properties decrease too, and this may lead to the danger of cracking appearance and pipe rupture while being in service.

Substandard pipe stringing and pipe laying into the trench often cause shape damages of the pipeline. The main welding faults on site conditions are cracks, undercuts, lack of penetration joints, slag inclusions and others.

Declining from typical pipeline operating modes while starting or interrupting operating of pump stations, transportation of different sorts of product in series, switching on or shutting down separate pump units, etc. causes episodic considerable pressure increase which may have higher value than the acceptable one. Incorrect line valves switching may cause significant hydraulic surge phenomena and as a result lead even to decompression of the pipeline.

Literature review. As a rule, most oil pipelines' depressurizing is caused by two groups of factors [5, 6]. The first group concerns reduction of loading capability of oil pipeline, the second - load and impact increase. Reduction of loading capability of oil pipeline is caused by mismatching of pipe wall characteristics and material wear. The second group of factors appears in the process of oil pipeline operation due to the temperature influence of the pumped product on the surrounding soil, soil pressure, various static and dynamic loads, surface deformation on construction sites, seismic activities.

The results of refusal analysis $[7,8]$ testify that one of the most valuable reasons of pipeline damages is the influence of external forces (conducting unauthorized activities in the oil pipeline right of way including spontaneous traffic crossings in unequipped sites, landslides, earthquakes, explosions, and others), causing formation of surface dents, cracks, dent cracks 
or even line rupture. The most common are damages occurring by the reason of conducting any repair or construction activities very close to the pipeline surface. They belong to the group of the most dangerous damages. Due to the influence of external factors, according to [8], at main oil pipelines there take place only about $5 \%$ of all accidents, but by the extent of the damages, they possess the first place.

Corrosion damages of oil pipelines occur under chemical and electrochemical oxidation processes of pipe metal due to ruining of metal protection surface and the presence of corrosive medium.

According to the nature of the interaction of metal with the environment, there are two main types of corrosion: chemical and electrochemical.

Chemical corrosion occurs according to the laws of chemical kinetics of heterogeneous reactions, i.e. without the presence of electric current in the metal. This type of corrosion is divided into gas corrosion (the interaction of metal with gaseous oxygen or other gas under intense thermal conditions without any moisture on the metal surface) and corrosion in non-electrolytes (oxidation of metal in liquid corrosive medium with low electrical conductivity).

Electrochemical corrosion is the oxidation of metal in electrolytes with appearing of electric current in it. In this case, the so-called cathodic and anodic zones appear on separate parts of the pipe surface. The latter activates the process of oxidation of metal. In addition, corrosion can occur with the simultaneous action of the corrosive medium and mechanical stresses in the metal. Corrosive processes in pipelines occur under the influence of ground, stray currents and alternating current of electrified transport [3].

According to the analysis of the results of the oil pipeline accident studies $[9,10]$, it can be stated that accidents on the line due to external corrosion take up 30-35\% of their total number.

Pipe defects as any inconsistency of controlled parameter with the regulated norms can be classified into two types: internal (metallurgical) and external (mechanical). Metallurgical defects include defects of pipe metal: non-metallic slag and flux inclusions, shuts, corrosion, coking, overheating, burning out, gas bubbles, different thickness of the sheets, internal gaps, shrinkage bubbles, cracks (hydrogen, hot, thermal, fatigue, and so on), flakes and others. Mechanical defects include defects of pipe wall: scratches, notches, rags, dents with different geometric characteristics (depth, radius of curvature, length, and so on), erosive destruction of the inner surface of pipe, cracks arising from violations of the rolling technology, dents formed from pressing scale by rollers, metal crumbs or incidental shocks.

Defects of welds include: facings (leakings), joints inconsistent in length, width and height, rough scales of a joint, undercuts, cracks, lacks of penetration, pores, piercing, and others.

Facings are more frequently formed during welding of vertical surfaces by horizontal joints as a result of liquid metal leaking on the edges of cold base metal. The reasons for occurrence of facings are large power of welding current, long arc, wrong position of electrode.

Undercuts are deepenings (grooves) formed in base metal along the edge of welds at a high welding current and a long arc. Undercuts lead to weakening of cross-section of base metal and can cause the destruction of welded joints.

Unsolved aspects of the problems. The analysis of research results concerning causes of main oil pipelines failure [3, 11] shows that the share of refusals occurred due to neglecting the rules of technical operation of main oil pipelines ranges from 2 to $7 \%$. These include refusals due to the personnel's faults in observing the safety rules and wrong management decisions that lead to violation of terms and quality of maintenance and repair.

Additional external loads include hydraulic impacts arising as a result of breaking the rules of operation and cause the destruction of pipeline. They are a great danger to pipelines.
Hydraulic surges may be the result of a sudden shutdown of pumping stations or false closure of valves, as well as formation of air congestions in pipeline, which in some cases can cause pressure fluctuations similar to hydraulic impact $[5,11]$.

The analysis of statistics of oil pipeline accidents shows the following distribution of reasons:

- external physical activities applied to pipelines including criminal cut-ins, causing leakage $-34.7 \%$;

- breaking the standards and rules of conducting construction and maintenance works, deviation from project decisions $-24.7 \%$;

- corrosive damages of pipes, isolation and control valves $23.5 \%$

- wrong activities of production and maintenance personnel $-12.4 \%$

- breaking specifications in manufacture of pipes and equipment.

Considering significant term of Ukrainian oil transporting system operation we can confirm that sudden pressure fluctuations in pipelines result in emergency situations combined with pipeline rupturing. Thus, transient processes caused by production changes are undesirable or even dangerous. They mostly refer to processes with a leap-like reduction of oil collection from a pipeline; otherwise they may lead to hydraulic blow in the pipeline with all the consequences.

Purpose. The common theory of hydraulic blow is welldeveloped nowadays. General principles of the process particularly the degree of pressure increase in pipes, its frequency and fluctuation amplitude, attenuation decrement are described in the works $[12,13]$. However, the above mentioned processes in complex oil-transporting systems have more complicated character that requires additional research.

Methods. We deal with oil-transporting system, which consists of main oil pipeline having $L$ length with focused road collection of oil at a definite point at $l$ distance from the beginning. Before the transient process $(t=0)$ the system was in a stationary mode with mass oil discharge $m_{0}$ and pressure at the starting point $(x=0)$ is $P_{0}$; at the trace point with coordinate $x_{i}$ there is a road focused oil collection marked $M_{i}$. At the certain period of time $(t>0)$ a leap-like reduction of oil collection to mass discharge $m_{L}<m_{0}$ is being observed. It is necessary to build a mathematic model of transient process and to establish its characteristics.

An analytical model of transient process is based on the equations of motion and continuity such as [14, 15]

$$
\begin{gathered}
-\frac{\partial P}{\partial x}=\frac{\lambda \rho w^{2}}{2 d}+\frac{\partial(\rho w)}{\partial t} ; \\
-\frac{\partial P}{\partial t}=c^{2} \frac{\partial(\rho w)}{\partial x},
\end{gathered}
$$

where $P(x, t), w(x, t)$ are pressure and oil velocities in pipes correspondingly as functions of linear coordinate $x$ and time $t$; $\lambda$ is the friction factor; $\rho$ is oil density; $d$ is the internal diameter of the pipeline; $c$ is acoustic wave velocity in the pipeline.

On linearization of motion equation $\left(2 a=\frac{\lambda w}{2 d}\right)$ and considering road selection in continuity equation the system (1) looks like this

$$
\begin{gathered}
-\frac{\partial P}{\partial x}=\frac{2 a}{F} m+\frac{1}{F} \frac{\partial m}{\partial t} ; \\
\frac{1}{c^{2}} \frac{\partial P}{\partial t}+\frac{1}{F} \frac{\partial m}{\partial x}-\frac{M_{i}}{F} \delta\left(x-x_{i}\right)=0,
\end{gathered}
$$

where $m(x, t)$ is mass flowrate as a function of linear coordinate and time; $M_{i}$ is the averaged value of mass flowrate; $\delta(x-$ $-x_{i}$ ) is the function of Dirac's source.

The system (2) is built to equation 


$$
\delta \cdot\left(x-x_{i}\right)=\frac{d}{d x}\left[\delta\left(x-x_{i}\right)\right]
$$

where $\chi=\frac{c^{2}}{2 a} ; \quad \delta^{\bullet}\left(x-x_{i}\right)=\frac{d}{d x}\left[\delta\left(x-x_{i}\right)\right]$,

The initial and boundary conditions for integration (3) have the following form

$$
m(x, 0)=m_{0} ; \quad m(0, t)=m_{0} ; \quad m(L, t)=m_{L} .
$$

The realization (3) at initial and boundary conditions (4) is carried out by the method of integral transformations, in particular the Fourier sine-transform is used [8]

$$
P_{m}=\frac{2}{L} \int_{0}^{L} m(x, t) \sin \frac{\pi n x}{L} d x .
$$

Considering (5) the equation (3) in the domain of integral transformations has the form

$$
\begin{aligned}
& \frac{1}{c^{2}} \frac{d^{2} P_{m}}{d t^{2}}+\frac{1}{\chi} \frac{d P_{m}}{d t}+\left(\frac{\pi n c}{L}\right)^{2} P_{m}= \\
= & \frac{2 \pi n}{L^{2}}\left[m_{0}-(-1)^{n}\right]+\frac{2 \pi n}{L^{2}} M_{i} \cdot \cos \frac{\pi n x_{i}}{L} .
\end{aligned}
$$

The derivation (6) is obtained in the form of

$$
P_{m}=\frac{2}{\pi n}\left[m_{0} A_{n}\left(1+\frac{C_{n}}{A_{n}}\right) e^{-a t} \cos \lambda_{n} t\right],
$$

where

$$
\begin{gathered}
A_{n}=1-\frac{m_{L}}{m_{0}}(-1)^{n}+\frac{M_{i}}{m_{0}} \cdot \cos \frac{\pi n x_{i}}{L} ; \\
C_{n}=\left(1+\frac{m_{L}}{m_{0}}+\frac{M_{i}}{m_{0}}\right)(-1)^{n}-\frac{2 M_{i}}{m_{0}} \cos \frac{\pi n x_{i}}{L} ; \\
\lambda_{n}=\sqrt{a^{2}-\left(\frac{\pi n c}{L}\right)^{2}} .
\end{gathered}
$$
dure

The transition from the image area is based on the proce-

$$
m(x, t)=\sum_{n=1}^{\infty} P_{m} \sin \frac{\pi n x}{L} .
$$

As a result, we obtain

$$
m(x, t)=\frac{2}{\pi} \sum_{n=1}^{\infty}\left\{\frac{1}{n}\left[m_{0} A_{n}\left(1+\frac{C_{n}}{A_{n}}\right)\right] e^{-a t} \cos \lambda_{n} t \sin \frac{\pi n x}{L}\right\} .
$$

To determine the pressure as a function of linear coordinate and time, we use the first equation of the system (2). After simple transformations we obtain

$$
\begin{gathered}
P(x, t)=P_{0}+\frac{2 L}{F \pi^{2}} \times \\
\times \sum_{n=1}^{\infty}\left\{\frac { 1 } { n ^ { 2 } } m _ { 0 } A _ { n } ( 1 + \frac { C _ { n } } { A _ { n } } ) \left[(a-1) \cos \lambda_{n} t-\right.\right. \\
\left.\left.-\lambda_{n} \sin \lambda_{n} t\right] e^{-a t} \cos \frac{\pi n x}{L}\right\} .
\end{gathered}
$$

It should be noted that taking the value of mass flow $m_{L}=0$ and $M_{i}=0$ in (10), we pass to the problem of direct hydraulic impact in a simple oil pipeline.

Based on (10) the calculations of the transient process are carried out in the hypothetical oil pipeline with the length of $80 \mathrm{~km}$ and diameter of $529 \cdot 10 \mathrm{~mm}$ with a concentrated leakage located at a distance of $30 \mathrm{~km}$ from the beginning with a massive flow of $3 \%$ of the initial stationary flow, and at the end of the pipeline the flow intermittently decreases to $60 \%$. The results of the calculations presented in Fig. 1 in the form of charts express the dependences of the initial and final pressures and pressure at the point of time selection. Their analysis shows that the perturbation of the pressure wave spreading along trace with the speed of sound is characterized by a significant increase of pressure during the initial $10-15 \mathrm{~s}$ depending on the linear coordinate. The subsequent process of pressure fluctuation lasting for up to $30 \mathrm{~s}$ will not have dangerous consequences in terms of breaking the strength of the pipeline because of increased pressure. Therefore, from a practical point of view, the oscillatory process in the oil pipeline is of interest during the initial $10-15 \mathrm{~s}$.

It should be noted that the derivation (10) inadequately reflects the nature of the pressure fluctuation in oil pipeline since the boundary conditions predict the constancy of mass flow of time-varying road selection. A mathematical model that takes into account the fluctuations of mass flow of time-varying selection of the transient process will be characterized by extraordinary complexity in construction and implementation. Meanwhile the influence of change of flow of time-varying selection may insignificantly affect the process characteristics. In order to assess the impact of changing the flow of time-varying selection upon the nature of pressure fluctuation in oil pipeline caused by changing of oil flow, the iterative procedure is used.

As it is known, changing the orifice discharge of fluid in a thin wall depending on the internal pressure can be characterized by equation

$$
\begin{gathered}
m\left(x_{i}, t\right)=\mu \omega \rho \sqrt{2 g H}=\mu \omega \rho \sqrt{2 g \frac{P\left(x_{i}, t\right)-P_{e n v}}{g \rho}}= \\
=\mu \omega \sqrt{2 \rho\left(P\left(x_{i}, t\right)-P_{e n v}\right)},
\end{gathered}
$$

where $\mu$ is the discharge coefficient; $\omega$ is a discharge area; $\rho$ is fluid density; $H$ is excessive discharge head in the oil pipeline; $P_{e n v}$ is pressure resistance of the environment.

If concentrated selection is a branch pipe of length $l$ and of internal diameter $d$ with drag coefficient $\lambda$ and final pressure $P_{K}$, then mass flow can be found on the basis of Darcy's equation

$$
P\left(x_{i}, t\right)-P_{e n v}=\frac{8 \lambda l m^{2}\left(x_{i}, t\right)}{\pi^{2} d^{5} \rho} .
$$

Equations (11) and (12) give the connection between the pressure in oil pipeline at the point of selection $P\left(x_{i}, t\right)$ determined on the basis of (10) and mass orifice discharge $m\left(x_{i}, t\right)$; however it is unrealistic to use it when creating a mathematical model of the process. Therefore, it is proposed to use the iteration method the essence of which is the following.

Let us suppose that mass orifice discharge was almost constant by the moment of time $t_{1}$ and was $m_{0}$. Under these condi-

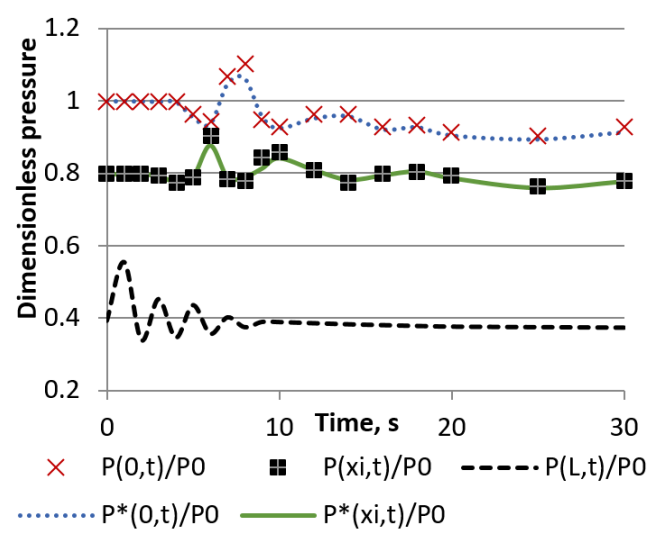

Fig. 1. Nature of the pressure fluctuation in the oil pipeline during the process of hydraulic impact 
tions an equation (10) is obtained; so it is legitimate to use it to determine the nature of pressure fluctuation. Having the pressure in oil pipeline at the point of selection $P\left(x_{i}, t\right)$ it is possible to create the graph of time-varying change of orifice discharge $m\left(x_{i}, t\right)$ on the basis of (11) or (12) (Fig. 2) which can be replaced by the piecewise continuous function, which will allow determining the mass flow rate $m_{1}$ at the moment of time $t_{1}$. Considering the rate of flow $m_{1}$ as unchangeable over a period of time $\left(t_{1}, t_{2}\right)$, we predict the change of pressure in the pipeline during this period of time by means of (10). On the basis of prediction, we determine the value of pressure at the point of selection $P^{*}\left(x_{i}, t\right)$.

We control the fulfilment of the condition by setting a certain permissible error in determining the pressure $\delta P$

$$
\left|P\left(x_{i}, t\right)-P^{*}\left(x_{i}, t\right)\right| \leq \delta P .
$$

If the condition is not fulfilled, we accept $P\left(x_{i}, t\right)=P^{*}\left(x_{i}, t\right)$ and return to definition of mass flow of selection $m^{*}\left(x_{i}, t\right)$ from dependencies (11) or (12). After fulfilling of this condition, the values of pressures $P^{*}(0, t), P^{*}\left(x_{i}, t\right), P^{*}(L, t)$ and mass flow $m^{*}\left(x_{i}, t\right)$ for the period of time $\left(t_{1}, t_{2}\right)$ are recorded and we proceed to the next period of time. Thus, we obtain dependencies which describe the nature of pressure oscillations in oil pipeline under the condition of a leap-like change of mass flow selection.

The pressure dependences constructed in this way in the characteristic points of trace of oil pipeline as a function of time are presented in the form of graphs in Fig. 1. The analysis of results of the study shows an insignificant influence of change of mass flow rate of product selection upon the nature of time-varying pressure oscillations at characteristic points of oil pipeline. Fig. 3 shows the dependence of the relative difference in the results of prediction of the transient process with and without taking into account the change of mass flow rate of selection.

Maximum difference in calculation results does not exceed $3.3 \%$; moreover, it is typical for the moments of time in which

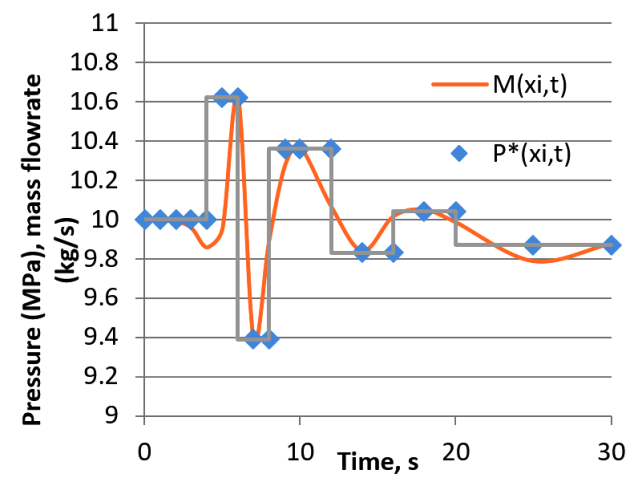

Fig. 2. Dynamics of change in orifice discharge and their piecewise continuous approximation

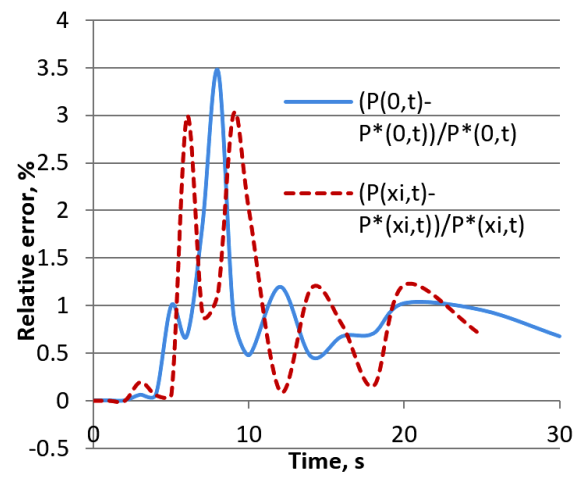

Fig. 3. Difference in results of calculation the amplitude of the oscillation process is maximal. Furthermore, it has been established that with an increasing distance from the source of perturbation the, difference in results increases. For the pressure oscillations at the point of perturbation $x=L$, the difference in results is practically absent.

Conclusions. Thus, the results of the research allow predicting the nature of the transient process of pressure fluctuations in petroleum-based system caused by a leap-like change in selection of pumped product, establishing the amplitudefrequency characteristics of the process and estimating accuracy prediction. The results obtained can be used in oil pipelines and complex petroleum-based systems operating under incomplete loading associated with frequent change in productivity to prevent emergencies.

\section{References.}

1. Hryhorskyi, S. Y. (2014). Methods of reducing the negative impact of transient processes caused by pumping unit stops upon the pipeline operating modes. Naukovyi Visnyk IvanoFrankivskoho Natsionalnoho Tekhnichnoho Universytetu Nafty $i$ Hazu, (2), 128-139.

2. Tarr, B. A., Ladendorf, D. W., Sanchez, D., \& Milner, G. M. (2016). Next-Generation Kick Detection During Connections: Influx Detection at Pumps Stop (IDAPS) Software. Society of Petroleum Engineers. SPE Drilling \& Completion, 31(04), 1-15. https://doi.org/10.2118/178821-PA.

3. Skuridin, N. N., Tyusenkov, A.S., \& Bugay, D. E. (2018). Increasing the safety of main oil pipelines based on optimization of electrochemical protection parameters. Neftianoe khoziaistvo, (08), 92-95. https://doi.org/10.24887/0028-24482018-8-92-95.

4. Hrabovskyi, R.S., Lepak, O.M., Mazur, M.P., Fedorovych, I. Y., \& Barna, R. A. (2015). Estimation of ruining conditions of long-term operation pipelines. Naukovyi Visnyk Ivano-Frankivskoho Natsionalnoho Tekhnichnoho Universytetu Nafty i Hazu, (1), 46-53.

5. Lisafin, V.P. (2017). Peculiarities of intra-stationary oil pumping at pumping stations of main oil pipeline. International Scientific Journal "Internauka”, 8(30), 49-53.

6. Sobolev, S.A. (2018). Consecutive operation of booster pumping stations in conditions of periodic communication sessions. Oil Industry Journal, (3), 54-57.

7. Grudz, V.Y., Zhdek, A., \& Bolonnyi, V.T. (2016). Estimation of flow rate of oil loss as a result of damage of linear part of oil main. Metallurgical and Mining Industry, (6), 75-78.

8. Khalaf, A.M., Al Omari, A.M., Al-Sherif, A.H., Toubar, A., Barsoum, I., \& Karrech, A. (2017). Main Oil Line Pump Seal Failure Prevention; Advanced Simulation and Case Study. Society of Petroleum Engineers, November 13, 1-8. https://doi.org/10.2118/188626-MS.

9. Elchalakani, M., Almaskari, F., Alardhi, M., Alkhrdaji, T., \& Hill, C. (2015). CFRP Strengthening and Rehabilitation of Corroded Steel Pipelines Under Direct Indentation and Bending. Society of Petroleum Engineers, November 9, 1-15. https://doi.org/10.2118/177876-MS.

10. Levold, E., Restelli, A., Marchionni, L., Vitali, L., Molinari, C., \& Ozkan, I. F. (2015). Strength and Deformation Capacity of Corroded Pipe: Laboratory Tests and FEM Analyses. The International Society of Offshore and Polar Engineers, 25(3), 212-220.

11. Vozniak, L. V., Kryvenko, H. M., \& Vozniak, M. P. (2017). Analysis of emergency oil losses due to defective holes in industrial pipelines. In International scientific and technical conference "Oil and gas energy - 2017", (pp. 377-379). IvanoFrankivsk. 15-19 May 2017. Retrieved from http://elar.nung. edu.ua/bitstream/123456789/6014/1/6614p.pdf.

12. Zapukhliak, V., Poberezhny, L., Maruschak, P., Grudz Jr., V., Stasiuk, R., Brezinová, J., \& Guzanová, A. (2019). Mathematical modeling of unsteady gas transmission system operating conditions under insufficient loading. Energies, 12(7), 1-14. EISSN 1996-1073. 
13. Salehi, A., Voskov, D. V., \& Tchelepi, H. A. (2017). K-Values Based Non-Equilibrium Formulation for Upscaling of Compositional Simulation. In Society of Petroleum Engineers. SPE Reservoir Simulation Conference, 20-22 February, 2017, (pp. 1-20). Montgomery, Texas, USA. https://doi. org/10.2118/182725-MS.

14. Sumskoi, S. I., Sverchkov, A. M., Lisanov, M.V., \& Egorov, A.F. (2016). Modelling of non-equilibrium flow in the branched pipeline systems. Journal of Physics: Conference, Series 751,1-8.https://doi.org/10.1088/1742-6596/751/1/012022. 15. Grudz, V.Ya., Grudz Jr., V.Ya., Zapukhlyak, V.B., \& Kyzymyshyn, Ya. V. (2018). Non-stationary processes in the gas transmission systems at compressor stations shut-down. Journal of hydrocarbon power engineering, 1(5), 22-28.

\section{Прогнозування нестаціонарних процесів у нафтопроводах з метою запобігання виникненню аварійних ситуацій}

\author{
В. Т. Болонний', В. Я. Грудз ${ }^{2}$, Я. В. Грудз ${ }^{2}$, \\ В. Б. Запухляк $\kappa^{2}$ Т. Я. Додик ${ }^{3}$
}

1 - Дрогобицький коледж нафти і газу, м. Дрогобич, Львівська область, Україна, e-mail: vtb281972@ukr.net

2 - Івано-Франківський національний технічний університет нафти і газу, м. Івано-Франківськ, Україна, е-mail: v.grudz@nung.edu.ua

3 - АТ «Укртранснафта», м. Броди, Львівська обл., Україна, е-mail: taras.dodyk@ukr.net

Мета. Запобігання аварійності при експлуатації складних нафтотранспортних систем в умовах неповного завантаження на основі прогнозування характеру протікання нестаціонарних процесів пульсації тиску, викликаних стрибкоподібною зміною продуктивності.

Методика. Проаналізовані основні чинники, що впливають на безаварійність роботи магістральних нафтопроводів. Приведена класифікація дефектів стінки труби магістральних нафтопроводів. Для кожного з наведених видів дефектів зазначені ймовірнісні показники їх виникнення виходячи з досвіду експлуатації вітчизняних магістральних нафтопроводів.

Результати. Для проведення аналітичних досліджень і встановлення закономірностей коливання тиску в магістральному нафтопроводі із шляховим відбором створена математична модель, що базується на рівняннях руху й нерозривності середовища, зосереджений відбір в якій моделюється з використанням функції джерела Дірака. Реалізація моделі здійснювалась із використанням принципів операційного числення, що дозволило отримати аналітичну форму характеру коливання в часі тисків у характерних точках траси, яка надасть можливість встановити амплітудно-частотні характеристики нестаціонарного процесу.

Наукова новизна. Уперше запропоновано використовувати кусково-лінійну апроксимацію граничних умов у місці виникнення витоку для використання їх в аналітичному розв'язку моделі нестаціонарного процесу в гіпотетичному магістральному нафтопроводі.

Практична значимість. За отриманою методикою побудовано розподіл відносних значень тиску та масової витрати в характерних точках модельної нафтопровідної системи. Проведена оцінка впливу зміни в часі похибки визначення тиску на шляховому відборі на точність проведених обчислень. Отримані результати рекомендується використовувати при експлуатації нафтопроводів i складних нафтопровідних систем, що працюють в умо- вах неповного завантаження (для запобігання виникненню аварійних ситуацій).

Ключові слова: складна нафтотранспортна система, шляховий відбір, зміна витрати, коливання тиску

\section{Прогнозирование нестационарных процессов в нефтепроводе с целью предотвращения возникновения аварийных ситуаций}

\author{
В. Т. Болонный, В. Я. Грудз ${ }^{2}$ Я. В. Грудз ${ }^{2}$, \\ В. Б. Запухляк $\kappa^{2}$ Т.Я.Додык
}

1 - Дрогобычский колледж нефти и газа, г. Дрогобыч, Львовская область, Украина, e-mail: vtb281972@ukr.net 2 - Ивано-Франковский национальный технический университет нефти и газа, г. Ивано-Франковск, УкраиHa, e-mail: v.grudz@nung.edu.ua

3 - АО «Укртранснафта», г. Броды, Львовская область, Украина, e-mail: taras.dodyk@ukr.net

Цель. Предотвращение аварийности при эксплуатации сложных нефтетранспортных систем в условиях неполной загрузки на основе прогнозирования характера протекания нестационарных процессов пульсации давления, вызванных скачкообразным изменением производительности.

Методика. Проанализированы основные факторы, влияющие на безаварийность работы магистральных нефтепроводов. Приведена классификация дефектов стенки трубы магистральных нефтепроводов. Для каждого из приведенных видов дефектов отмечены вероятностные показатели их возникновения исходя из опыта эксплуатации отечественных магистральных нефтепроводов.

Результаты. Для проведения аналитических исследований и установления закономерностей колебания давления в магистральном нефтепроводе с путевым отбором создана математическая модель, базирующаяся на уравнениях движения и неразрывности среды, сосредоточенный отбор в которой моделируется с использованием функции источника Дирака. Реализация модели осуществлялась с использованием принципов операционного исчисления, что позволило получить аналитическую форму характера колебания во времени давления в характерных точках трассы, которая позволит установить амплитудночастотные характеристики нестационарного процесса.

Научная новизна. Впервые предложено использовать кусочно-линейную аппроксимацию граничных условий в месте возникновения утечки для использования их в аналитическом решении модели нестационарного процесса в гипотетическом магистральном нефтепроводе.

Практическая значимость. По полученной методике построено распределение относительных значений давления и массового расхода в характерных точках модельной нефтепроводной системы. Проведена оценка влияния изменения во времени погрешности определения давления на путевом отборе на точность проведенных вычислений. Полученные результаты рекомендуется использовать при эксплуатации нефтепроводов и сложных нефтепроводных систем, работающих в условиях неполной загрузки (для предотвращения возникновения аварийных ситуаций).

Ключевые слова: сложная нефтетранспортная система, путевой отбор, изменение расхода, колебания давления

Recommended for publication by D.F. Tymkiv, Doctor of Technical Sciences. The manuscript was submitted 13.11.18. 